\title{
Aktuálne otázky vyporiadania bezpodielového spoluvlastníctva manželov
}

\author{
Juraj Takáč * \\ DOI: https://doi.org/10.24040/sap.2021.8.4.321-330
}

\begin{abstract}
Abstrakt:
TAKÁČ, Juraj: Aktuálne otázky vyporiadania bezpodielového spoluvlastníctva manželov. Predmetný príspevok sa snaží reflektovat' na aktuálne otázky týkajúce sa vyporiadania bezpodielového spoluvlastníctva manželov. Ciel'om je poukázat' na občianskoprávnu reguláciu tohto procesu a zároveň zamerat' sa na súvisiacu súdnu prax. Príspevok podrobne analyzuje jednotlivé spôsoby vyporiadania bezpodielového spoluvlastníctva manželov s reflekciou na príslušnú judikatúru.

\section{Kl'účové slová:}

Bezpodielové spoluvlastníctvo manželov, vecné práva, Občiansky zákonník, súkromné právo, zánik manželstva, rozvod
\end{abstract}

\section{Current Issues of Settlement of Community Property of Spouses}

\begin{abstract}
:
TAKÁČ, Juraj: Current Issues of Settlement of Community Property of Spouses. This article seeks to reflect on current issues related to settlement of community property of spouses. The aim is to point out the civil law regulation of this process and at the same time to focus on the relevant court decisions. The article analyzes in detail individual ways of settling community property of spouses with a reflection on the relevant case law.
\end{abstract}

\section{Key words:}

Community property of spouses, rights in rem, Civil Code, private law, dissolution of marriage, divorce

\section{Úvod}

Vyporiadanie bezpodielového spoluvlastníctva manželov je neodvratným následkom jeho zániku. V zmysle súčasne platnej legislatívy, bezpodielové spoluvlastníctvo manželov, ako jeden z dvoch druhov spoluvlastníctva, môže vzniknút' a existovat' iba za trvania manželstva. Predstavuje to určitú formu akcesority existencie BSM od existencie manželstva. Predmetné pravidlo vyplýva priamo z ustanovenia $\S 148$ ods. 1 Občianskeho zákonníka, podl’a ktorého zánikom manželstva zanikne i bezpodielové spoluvlastníctvo manželov. Toto ustanovenie je kogentné, a preto strany sa nemôžu od

* JUDr. PhD., Juraj Takáč, Právnická fakulta Univerzity Mateja Bela v Banskej Bystrici, Katedra občianskeho a pracovného práva, odborný asistent 
neho odchýlit'. Naša legislatíva nepripúšt’a, aby mohlo bezpodielové spoluvlastníctvo manželov existovat' bez ohl'adu na trvanie manželstva. Zároveň predmetná forma spoluvlastníctva, tak ako vyplýva aj zo samotného názvu, sa výlučne viaže na manželstvo, a teda nemôže vzniknút' $v$ rámci iných foriem spolunažívania fyzických osôb (osoby žijúce v spoločnej domácnosti, partnerské zväzky). Je pravdepodobné, že vzhl'adom na spoločenský vývoj a trend, kedy čoraz viac párov žije spoločne a zakladajú si rodinu bez uzavretia manželstva, dôjde k určitým zmenám v právnej regulácii podmienok vzniku BSM, resp. prinajmenšom k zavedeniu inštitútu, ktorý by mal obdobné charakteristické vlastnosti a funkciu ako BSM a bol by aplikovatel'ný vo vzt'ahu k osobám, ktoré spoločne žijú, avšak nemajú uzavreté manželstvo.

\section{Vyporiadania bezpodielového spoluvlastníctva manželov}

Na ustanovenie $§ 148$ ods. 1 Občianskeho zákonníka nadväzuje ustanovenie 149 OZ, v zmysle ktorého, ak dôjde k zániku bezpodielového spoluvlastníctva manželov, sa vykoná jeho vyporiadanie. Vyporiadanie predstavuje určitú formu rozdelenia majetku, ktorý manželia nadobudli do svojho bezpodielového spoluvlastníctva počas manželstva.

Občiansky zákonník všeobecne vymedzuje spôsoby vyporiadania BSM, a to bud' na základe dohody bývalých manželov, na základe rozhodnutia súdu, alebo priamo na základe zákona. Aplikácia jednotlivých spôsobov vyporiadania bezpodielového spoluvlastníctva sa odvíja od toho, ako a či vôbec sú manželia schopní a ochotní si spoločný majetok nadobudnutý za trvania manželstva vyporiadat'. ${ }^{1}$

\section{Vyporiadanie bezpodielového spoluvlastníctva manželov na základe dohody}

Najjednoduchší a aj najefektívnejší spôsob vyporiadania majetku spadajúceho do zaniknutého BSM je formou dohody medzi bývalými manželmi. ${ }^{2}$ Občiansky zákonník

1 Rozhodnutie Ústavného súdu Slovenskej republiky, sp. zn.: II. ÚS 395/2010: Do vyporiadania bezpodielového spoluvlastníctva manželov treba na rozvedených manželov hl'adiet' ako na rovnocenných vlastníkov, čo sa týka kvantity i kvality ich bezpodielového spoluvlastníckeho práva. V prípade nezhôd bývalých (rozvedených) manželov, v súvislosti s výkonom jednotlivých atribútov vlastníckeho práva $\mathrm{k}$ ich spoločnému majetku, rozhodne o ochrane tohto atribútu na návrh niektorého z nich všeobecný súd (§ 146 ods. 1 OZ). Do vyporiadania bezpodielového spoluvlastníctva, resp. do doby, ked' niet zákonného právneho podkladu, jeden z manželov nemôže bývalému manželovi, ktorý je sám v rovnakom rozsahu a kvalite ako druhý manžel vlastníkom predmetu bezpodielového spoluvlastníctva, prenechat' svoje užívacie právo $\mathrm{k}$ tomuto predmetu bezpodielového spoluvlastníctva, napríklad do nájmu, ani do obdobného vzt'ahu odplatného užívania.

2 Rozhodnutie Najvyššieho súdu Slovenskej republiky, sp. zn. 4 Cdo 181/2007: „Vyporiadanie bezpodielového spoluvlastníctva nemá charakter typického prevodu vlastníctva. Vyporiadaním sa teda vlastníctvo nezriad'uje, nenadobúda a nejde o žiaden prevod ani prechod. Na tomto závere nič nemeni ani ustanovenie § 149 a OZ, v zmysle ktorého pokial' sa dohody o vyporiadani bezpodielového spoluvlastnictva týkajú nehnutelností, musia mat' pisomnú formu a nadobúdajú účinnost' až vkladom do katastra. Vzhl'adom na chápanie bezpodielového spoluvlastnictva ako dvojitého úplného vlastníctva manželov, vkladom nenadobúda vlastníctvo ten, komu 
všeobecne nevymedzuje podmienky, aké by mala dohoda o vyporiadaní bezpodielového spoluvlastníctva manželov spíňat'. Analogicky sa však bude v takomto prípade postupovat' v zmysle všeobecných ustanovený Občianskeho zákonníka k právnym úkonom, ked’že takáto dohoda predstavuje dvojstranný právny úkon. Výslovne občiansky zákonník vo vzt'ahu k dohode o vyporiadaní BSM iba uvádza, že manželia sú povinní, v prípade ak jeden z nich o to požiada, si vzájomne vydat' písomné potvrdenie o tom, akým spôsobom sa vyporiadali.

Dané ustanovenie sa vzt’ahuje na prípady, kedy predmetom vyporiadania BSM sú výlučne hnutel'né veci, majetkové hodnoty a práva, ktoré sa nevzt'ahujú na nehnutel'nosti. V prípade ak by bola predmetom vyporiadania nehnutel'nost' (t.j. pozemok, alebo stavba spojená so zemou pevným základom), alebo majetkové právo (spoluvlastnícky podiel), je nevyhnutné v zmysle $\S 46$ ods. $1 \mathrm{OZ}$ mat' dohodu uzavretú v písomnej forme. Zároveň to výslovne vyplýva aj z ustanovenia $\S 149$ a, podl’a ktorého dohody medzi manželmi o vyporiadaní bezpodielového spoluvlastníctva manželov musia mat' písomnú formu, ak sa týkajú nehnutel'ností. ${ }^{3}$

Vyporiadanie bezpodielového spoluvlastníctva manželov dohodou medzi manželmi prichádza do úvahy v prípade zániku manželstva rozvodom, ${ }^{4}$ resp. vyhlásením manželstva za neplatné..$^{5}$ Nie je možné, aby k vyporiadaniu BSM došlo na základe dohody manželov v prípade zániku manželstva z titulu smrti jedného z manželov, zániku BSM za trvania manželstva $z$ dôvodu vyhlásenia konkurzu na majetok manžela, alebo pri zániku BSM za trvania manželstva z titulu uloženia trestu prepadnutia majetku jednému z manželov. V prípade smrti manžela k vyporiadaniu bezpodielového spoluvlastníctva dochádza v rámci konania o dedičstve. Ak došlo k zániku BSM počas manželstva z titulu uloženia trestu prepadnutia majetku, respektíve je dôvodom zániku BSM vyhlásenie konkurzu na majetok jedného z manželov, druhý manžel môže uzavriet' dohodu o vyporiadaní BSM, avšak iba so správcom konkurznej podstaty vo forme zmieru, ktorý musí schválit’ súd. ${ }^{6}$

nehnutel'nost' zostala, pretože vlastníctvo už má. Vkladom sa len potvrdzuje účinnost' dohody, že vlastníctvo sa mu ponecháva a druhý o neho prichádza."

3 Rozhodnutie Najvyššieho súdu Slovenskej republiky, sp. zn. 1 Sž-o-KS 139/2004: „Uzavretím dohody o vyporiadaní bezpodielového vlastníctva manželov dochádza $k$ prevodu vlastníctva. Ide o zmluvný prevod aj napriek tomu, že pri tomto prevode právna úprava poskytuje určité úlavy, prípadne nespája s ním tie povinnosti, ktoré platia všeobecne pri ostatných prevodoch. Pokial' sa dohoda medzi manželmi týka nehnutel'ností, musí mat' písomnú formu a nadobúda účinnost' vkladom do katastra. Pri zápise vkladu správa katastra musí postupovat' podla zásad platných pre vkladové konanie, teda aj podl'a § 31 ods. 1 katastrálneho zákona preskúmat', či právo nakladat's nehnutel'nost'ou nie je obmedzené a v prípade jeho zistenia návrh zamietnut'." Bližšie pozri: ust. § 22 a nasl. zákona č. 36/2005 Z.z. o rodine v platnom znení

5 Bližšie pozri: ust. § 9 - 16 zákona č. 36/2005 Z.z. o rodine v platnom znení

6 Ust. $\$ 53$ ods. 2 zákona č. 7/2005 o konkurze a reštrukturalizácii a o zmene a doplnení niektorých zákonov „Správca je oprávnený vykonat vyporiadanie bezpodielového spoluvlastníctva manželov zaniknutého vyhlásením konkurzu namiesto úpadcu vrátane podania návrhu na vyporiadanie bezpodielového spoluvlastníctva manželov prislušným súdom. Dohodu o vyporiadani bezpodielového spoluvlastníctva manželov je správca oprávnený uzavriet' len vo forme zmieru schváleného príslušným súdom.“ 


\section{Vyporiadanie bezpodielového spoluvlastníctva manželov na základe rozhodnutia súdu}

V prípade ak nedôjde k uzavretiu dohody o vyporiadaní BSM, nastupuje druhý spôsob vyporiadania, ktorý spočíva v súdnom rozhodnutí. Znamená to, že súd s prihliadnutím na pravidlá vyporiadania $\mathrm{v}$ zmysle $\S 150 \mathrm{OZ}$ rozhodne o tom, ako sa spoločný majetok manželov spadajúci do BSM prerozdelí. Takéto súdne konanie o vyporiadaní BSM sa začína výlučne na návrh. V závislosti od toho, z akého dôvodu došlo $\mathrm{k}$ zániku bezpodielového spoluvlastníctva manželov, návrh môže podat' manžel (aktívnu legitimáciu má ktorýkol'vek z nich), resp. správca konkurznej podstaty. Správca konkurznej podstaty podáva návrh tak v prípade, ak je vyhlásený konkurz na majetok jedného $\mathrm{z}$ manželov, ako ja v prípade uloženia trestu prepadnutia majetku jednému z manželov, ked'že aj $\mathrm{v}$ tomto prípade po vykonatel'nosti rozsudku, ktorým bol uložený trest prepadnutia majetku, je vec zaslaná konkurznému súdu, ktorý vyhlási na majetok odsúdeného manžela konkurz a následne vo veci dochádza $\mathrm{k}$ vyporiadaniu BSM v zmysle zákona č. 7/2005 Z.z. o konkurze a reštrukturalizácii. ${ }^{7}$

Existencia BSM sa viaže výlučne na existenciu manželstva. Z uvedeného je zrejmé, že ak dôvodom pre zánik BSM má byt' zánik manželstva, nie je možné, aby k jeho vyporiadaniu došlo pred tým, ako manželstvo fakticky zaniklo. Daná zákonná úprava je striktne kogentná, a preto nie je možné, aby manželia vyporiadali prostredníctvom dohody svoj majetok pred tým, ako dôjde k právoplatnosti rozhodnutia súdu, ktorým manželstvo rozvádza, resp. prostredníctvom dohody o vyporiadaní BSM pre prípad smrti jedného $\mathrm{z}$ manželov, ako ani pred vyhlásením konkurzu na majetok jedného z manželov.

Z uvedeného dôvodu vyporiadanie BSM nemôže byt' súčast'ou konania o rozvode (ako je tomu napríklad v prípade úpravy starostlivosti, styku a výživného pri maloletých det'och), ale musí sa podat' samostatný návrh na vyporiadanie, a to až po právoplatnom rozhodnutí o zániku manželstva rozvodom.

V prípade smrti jedného z manželov sa vyporiadanie uskutoční v rámci dedičského konania v zmysle ustanovenia $§ 195$ a 196 Civilného mimosporového poriadku. V rámci predmetného konania príslušný súd, prostredníctvom notára ako súdneho komisára, prejedná otázku vyporiadania BSM. Tu sa môžu pozostalý manžel a ostatní dedičia dohodnút', čo bude v rámci vyporiadania BSM spadat' do výlučného vlastníctva pozostalého manžela a čo bude predstavovat' predmet dedenia. ${ }^{8} \mathrm{~V}$ prípade ak by medzi pozostalým manželom a dedičmi k takejto dohode nedošlo, vyporiadanie bezpodielového spoluvlastníctva manželov uskutoční súd príslušný pre dané dedičské konania.

7 Ust. § 423 Trestného poriadku „Len čo sa stal rozsudok, ktorým bol uložený trest prepadnutia majetku, vykonatelným, zašle predseda senátu príslušnému konkurznému súdu rovnopis rozsudku bez odôvodnenia na postup podl'a osobitného zákona (zákon č. 7/2005 o konkurze a reštrukturalizácii a o zmene a doplneni niektorých zákonov).“

8 Rozhodnutie Najvyššieho súdu Slovenskej republiky, sp. zn. 4M Cdo 12/2009: „Majetok v bezpodielovom spoluvlastnictve sa môže vyporiadat' dohodou medzi pozostalým manželom a dedičmi uzavretou písomne alebo ústne do zápisnice. Dedič a pozostalý manžel (alebo jeho právni nástupcovia) sa môžu dohodnút’ aj tak, že celá masa bezpodielového spoluvlastnictva patrí do dedičstva a že pozostalému manželovi (resp. do dedičstva po ňom) patrí tzv. náhradová pohl'adávka." 
Súd rozhoduje o vyporiadaní BSM aj v prípadoch, ak dôjde k zániku bezpodielového spoluvlastníctva z titulu vyhlásenia konkurzu na majetok jedného z manželov.

Ako už bolo uvedené, žalobu na vyporiadanie BSM môže podat' ktorýkol'vek z manželov. ${ }^{9}$ Súd nie je viazaný žalobným návrhom z pohl'adu otázky kol'ko ktorému z manželov v rámci vyporiadania prisúdi. Súd rozhoduje rozsudkom, avšak ak manželia uzavreli zmier, schváli ho uznesením. Žalobu je nevyhnutné podat' na súd do troch rokov od zániku bezpodielového spoluvlastníctva manželov, pretože v opačnom prípade sa toto právo prekluduje a nastupuje zákonná nevyvrátitel'ná právna domnienka vyporiadania v zmysle ustanovenia $§ 149$ ods. 4 OZ.

\section{Vyporiadanie bezpodielového spoluvlastníctva manželov na základe zákona}

Predmetná nevyvrátitel'ná zákonná domnienka v zmysle $§ 149$ ods. 4 OZ stanovuje, že v prípade ak do troch rokov od zániku bezpodielového spoluvlastníctva manželov nedošlo k jeho vyporiadaniu dohodou, alebo nebol podaný návrh na vyporiadanie na súd, nastupuje vyporiadanie priamo zo zákona. Predmetná zákonná forma vyporiadania BSM sa aplikuje pre prípady, kedy nedošlo k vyporiadaniu dohodou a ani prostredníctvom súdu, a to či už v časti majetku spadajúceho do BSM, alebo v celom jeho rozsahu. ${ }^{10}$ Vzhl'adom na to, že dlhodobo pretrvávajúci stav nevyporiadania BSM dávno po tom, čo došlo k jeho zániku by mohol vyvolávat' značnú právnu neistotu, a to tak medzi manželmi/bývalými manželmi, ako aj vo vzt’ahu k tretím osobám, bolo nevyhnutné implementovat' do nášho právneho poriadku alternatívu vyporiadania BSM, ktoré by nastalo po určitom čase priamo zo zákona, a teda nezávisle od aktivity zúčastnených subjektov. Z uvedeného dôvodu ak manželia nezrealizujú vyporiadanie BSM včas, t.j. do troch rokov od zániku bezpodielového spoluvlastníctva, dôjde k takémuto vyporiadaniu automaticky priamo zo zákona.

V prípade dohody o vyporiadaní BSM je nevyhnutné, aby do troch rokov od zániku BSM došlo k jej uzavretiu. V prípade ak by takáto dohoda bola uzavretá po uplynutí

9 Rozhodnutie Ústavného súdu Slovenskej republiky, II. ÚS 244/2009: „V prípade, že každý $z$ bývalých manželov podal samostatný návrh na začatie konania vo veci vyporiadania ich bezpodielového spoluvlastnictva súdnym rozhodnutim, musi súd pri rozhodovani o zastaveni konania o návrhu takéhoto navrhovatel'a z dôvodu litispendencie podl'a § 83 OSP prihliadat' aj na to, aké dôsledky toto jeho rozhodnutie môže mat' vzhl'adom na súvisiace hmotné (\$149 ods. 4 OZ) a procesné predpisy ( $\$ 96$ ods. 1 a 3 OSP) a na jeho vlastnícke právo $k$ veciam, ktoré boli predmetom bezpodielového spoluvlastnictva.“

10 Rozhodnutie Najvyššieho súdu Slovenskej republiky, sp. zn. 4 Cdo 147/2011: „Jedným $z$ predpokladov, aby nastali účinky vyporiadania uvedené v \$ 149 ods. 4 OZ je existencia nevyporiadaného majetku, ktorý tvoril bezpodielové spoluvlastníctvo manželov, a to bud' celého bezpodielového spoluvlastnictva alebo jeho časti. Márnym uplynutím trojročnej zákonnej lehoty od zániku bezpodielového spoluvlastnictva manželov sa uplatni právny režim tohto ustanovenia (nevyvrátitel'ná právna domnienka) nielen v prípade, ked'v tejto lehote nedošlo $k$ jeho vyporiadaniu dohodou, alebo ak bezpodielové spoluvlastníctvo manželov nebolo na návrh podaný do troch rokov od jeho zániku vyporiadané rozhodnutím súdu, ale aj na tú čast' nevyporiadaného majetku, ktorý sa nezahrnul do súdneho rozhodnutia alebo do dohody účastníkov." 
danej zákonnej lehoty, takáto dohoda bude absolútne neplatná, ked’že právo na takúto dohodu sa uplynutím takejto lehoty prekluduje. Aj ked' nie je možné uzavriet' dohodu o vyporiadaní BSM po uplynutí zákonom stanovenej trojročnej lehoty, v prípade ak manželia podali v danej lehote návrh na vyporiadanie BSM na súd, nie je vylúčené, aby sa $\mathrm{v}$ rámci tohto konania dohodli a uzavreli súdny zmier. V prípade súdneho vyporiadania je dôležité, aby do troch rokov od zániku BSM došlo k podaniu návrhu ktorýmkol'vek z manželov na jeho vyporiadanie. $\mathrm{V}$ takom prípade sa bude vyporiadavat' BSM na základe rozhodnutia súdu, a to bez ohl'adu na to, či k samotnému reálnemu vyporiadaniu na základe súdneho rozhodnutia došlo počas stanovených troch rokov, alebo až po uplynutí zákonom stanovenej lehoty.

Občiansky zákonník práve v ust. § 149 ods. 4 určuje spôsob a pravidlá, akým $\mathrm{k}$ danému vyporiadaniu bezpodielového spoluvlastníctva manželov dôjde. V prípade hnutel'ných vecí patriacich do spoločného majetku sa prioritne zohl'adňuje to, čo ktorý z manželov výlučne užíval či už pre svoje potreby, resp. potreby svojej domácnosti v období troch rokov od zániku bezpodielového spoluvlastníctva. Tieto veci sa po uplynutí danej lehoty priamo pretransformujú do výlučného vlastníctva manžela, ktorý ich výlučne užíval. Príklad: Ak sa po rozvode (a teda zániku BSM) manžel odst'ahoval od manželky a zobral si so sebou televízor, počítač a mikrovlnnú rúru, ktoré spadajú do BSM, a tieto následne po dobu troch rokov od zániku BSM užíval iba on, predmetné veci sa stanú v rámci zákonného vyporiadania automaticky jeho výlučným vlastníctvom. V prípade hnutel'ných vecí, ktoré užívali aj nad’alej manželia spoločne, resp. sa striedali v užívaní, sa tieto po uplynutí zákonnej lehoty pretransformujú do podielového spoluvlastníctva, kde, ako vyplýva priamo z $§ 149$ ods. 4, každý z nich bude mat' na veci spoluvlastnícky podiel rovnakej vel'kosti (t.j. každý o vel'kosti $1 / 2 \mathrm{v}$ pomere $\mathrm{k}$ celku).

V prípade nehnutel'ných vecí je otázka výlučného užívania irelevantná a neprihliada sa na ňu. Zákon výslovne ustanovuje, že nehnutel'nosti sa zákonne vysporiadajú tak, že budú pretransformované do podielového spoluvlastníctva, kde každý z manželov bude nositel'om rovnako vel'kého spoluvlastníckeho podielu. Znamená to, že je nepodstatné, či v danom období predmetnú nehnutel'nost' užíval iba jeden z manželov alebo ju užívali obidvaja, nehnutel'nosti patriace do bezpodielového spoluvlastníctva manželov sa vždy pretransformujú do spoluvlastníctva podielového s rovnakými vel'kost’ami podielov obidvoch manželov. Ak by nastala situácia, že každý z manželov výlučne užíva čast' nehnutel'nosti, napr. rodinného domu (každý z manželov jednu izbu), pričom čast' nehnutel'nosti užívajú spoločne (napr. kuchyňa, chodba), na transformáciu vlastníckeho práva $\mathrm{k}$ danej nehnutel'nosti z BSM do podielového spoluvlastníctva, ako ani na vel'kost' jednotlivých spoluvlastníckych podielov, to nemá vplyv. Môže to však mat' vplyv na hnutel'né veci, ktoré manželia v danej nehnutel'nosti užívali. V prípade hnutel'ných vecí, ktoré každý užíval výlučne (napr. nábytok, elektronika, ktorú mali každý vo svojej izbe), tie sa stanú výlučným vlastníctvom každého z nich, avšak veci ktoré užívali obidvaja, napr. v spoločných priestoroch (nábytok v chodbe, príslušenstvo v kuchyni), tie budú už v ich podielovom spoluvlastníctve. ${ }^{11}$

11 Rozhodnutie Najvyššieho súdu Slovenskej republiky sp. zn. 5 Cdo 111/1997 „Ak manželia po dobu troch rokov od rozvodu uživali spoločný byt aj s bytovým zariadením tak, že každý 


\section{Vybrané otázky vyporiadania majetkových hodnôt, spoločných pohl'adávok a dlhov}

V prípade ostatných majetkových práv spadajúcich do bezpodielového spoluvlastníctva manželov sa postupuje obdobne ako je to pri nehnutel'nostiach, resp. hnutel'ných veciach uživaných obidvomi manželmi, a teda sa pretransformujú do podielového spoluvlastníctva. ${ }^{12}$ Daný spôsob vyporiadania sa uplatní aj v prípade spoločných pohl'adávok a záväzkov.

Práve vyporiadanie ostatných majetkových hodnôt a záväzkov v rámci bezpodielového spoluvlastníctva manželov sú všeobecne v značnej miera špecifické. Jedna z najdiskutovanejších otázok je vyporiadanie obchodného podielu. V takomto prípade sa zohl'adňuje prioritne to, či obchodný podiel bol nadobudnutý z prostriedkov spadajúcich do BSM alebo nie. V prípade ak iba čast' prostriedkov spadala do BSM, vyporiadavat' sa bude obchodný podiel v rozsahu zodpovedajúcemu časti vkladu, ktorý do bezpodielového spoluvlastníctva patril. ${ }^{13}$

Špecifikum obchodného podielu spočíva v tom, že samotné vyporiadanie BSM nemá vplyv na postavenie alebo zmenu spoločníka. Znamená to, že v prípade ak by iba jeden z manželov bol registrovaný ako spoločník obchodnej spoločnosti, jemu bude prikázaný daný obchodný podiel. Nemôže nastat' situácia, že by súd z dôvodu použitia spoločných prostriedkov prikázal daný podiel druhému manželovi, resp. by sa stali pomernými spoločníkmi v spoločnosti obidvaja manželia. Vzhl'adom na špecifickost' práv a povinností vyplývajúcich z obchodného podielu je tento sám o sebe prikázaný manželovi, ktorý je zaregistrovaný ako spoločník a vyporiadanie BSM nemôže spôsobit' zmenu spoločníka. Čo však je predmetom vyporiadania, tak to je hodnota obchodného podielu. Tu sa zohl'adňuje jeho obvyklá cena v čase vyporiadania a z nej následne bude alikvotne manželovi, ktorý nie je spoločníkom, prikázaná hodnota vyjadrená v peniazoch.

z nich užival vyčlenené časti bytu a zvyšok bytu uživali spoločne bez toho, aby vyporiadali bezpodielové spoluvlastnictvo dohodu alebo aby podali návrh na jeho vyporiadanie, došlo $k$ vyporiadaniu hnutelných veci nachádzajúcich sa v spoločnom byte zo zákona podl'a $\$ 149$ ods. 4 Občianskeho zákonnika tak, že veci uživané vo vyčlenených častiach bytu nadobudol každý z nich do výlučného vlastníctva a veci v spoločne uživaných častiach bytu nadobudli do podielového spoluvlastnictva."

12 Rozsudok Najvyššieho súdu Slovenskej republiky sp. zn. 2M Cdo 21/2005 „Ak do troch rokov od zániku manželstva zaniklo spoločné členstvo rozvedených manželov v družstve (\$ 705 ods. 2 Občianskeho zákonnika), môže sa po uplynutí tohto obdobia ten z rozvedených manželov, ktorý sa nestal členom družstva, úspešne domáhat' voči druhému manželovi zaplatenia polovice hodnoty členského podielu titulom vyporiadania spoločného majetkového práva za použitia analógie § 142 ods. 1 Občianskeho zákonnika.“

13 Rozsudok Najvyššieho súdu Slovenskej republiky, sp. zn. 2 Cdo 168/2005: „Obchodný podiel $v$ spoločnosti s ručením obmedzeným, nadobudnutý manželmi alebo jedným z nich za trvania manželstva a z prostriedkov patriacich do bezpodielového spoluvlastníctva manželov, predstavuje majetok (hodnotu), ktorý sa v rámci konania o vyporiadanie bezpodielového spoluvlastnictva manželov vyporiadava. Pri oceňovani obchodného podielu v spoločnosti s ručením obmedzeným v rámci vyporiadania bezpodielového spoluvlastníctva sa vychádza z jeho stavu v dobe zániku tohto spoluvlastnictva, avšak z obvyklej ceny v dobe vyporiadania.“ 
Obdobná situácia je aj v prípade podniku a podnikania jedného z manželov na základe živnostenského oprávnenia. Všeobecne aj tu platí premisa, že podnik ako taký patrí do výlučného vlastníctva manžela - podnikatel'a. Čo sa však týka výnosov z podnikania, tie už sú súčast'ou bezpodielového spoluvlastníctva. Preto v prípade spravodlivého vyporiadania BSM sa musí zohl'adňovat' to, kol'ko prostriedkov patriacich do BSM bolo použitých na podnikatel'skú činnost' manžela, kol'ko výnosov z podnikania bolo opätovne do podnikatel'skej činnosti vrátených a na základe týchto skutočností určit' rozsah aktív a pasív podniku a z toho stanovit' jeho hodnotu. Následne je podnikajúci manžel povinný nahradit' do bezpodielového spoluvlastníctva takú sumu, ktorá bude zodpovedat' kladnému rozdielu medzi aktívami a pasívami jeho podnikania.

Predmetom vyporiadania bezpodielového spoluvlastníctva manželov sú taktiež aj ich spoločné pohl'adávky a dlhy. Jedná sa o majetkové práva a záväzky, ktoré manželom vznikli v čase existencie BSM. V rámci vyporiadania zvyčajne budú tieto majetkové aktíva ako aj pasíva prerozdelené medzi manželov, a to principiálne v zmysle všeobecných pravidiel vyporiadania BSM v zmysle ust. § $150 \mathrm{OZ}$ (t.j. rovnost' podielov obidvoch manželov). ${ }^{14}$ Samozrejme aj dané pravidlo môže byt' modifikované, a to najmä s prihliadnutím na to, kto v akom rozsahu sa svojou činnost'ou, resp. nečinnost'ou zapríčinil o zadlženie.

Predmetné prerozdelenie pohl'adávok a dlhov manželov v rámci vyporiadania BSM bez ohl'adu na jeho formu (dohodou, súdnym rozhodnutím alebo zo zákona), však nemá účinky voči tretím osobám. Znamená to, že to ako sa manželia vyporiadajú, vo vzt'ahu k tretím osobám budú stále vystupovat' ako veritelia, resp. dlžníci solidárne. Ak by teda vyzval veritel' na plnenie manžela, ktorému na základe vyporiadania BSM nebol dlh prikázaný, je povinný si predmetný dlh voči veritel'ovi aj tak splnit', pričom následne z titulu vyporiadania BSM má voči druhému manželovi právo regresu.

$\mathrm{V}$ prípade ak by dohodou, resp. rozhodnutím súdu nedošlo k vyporiadaniu celého majetku spadajúceho do BSM (t.j. niektoré veci resp. majetkové hodnoty a práva by neboli manželmi vyporiadané), po uplynutí troch rokov od zániku bezpodielového spoluvlastníctva manželov sa na ne tiež bude aplikovat' pravidlo zákonné vyporiadania v zmysle $§ 149$ ods. 4 OZ.

\section{Záver}

Vyporiadanie bezpodielového spoluvlastníctva manželov predstavuje značne zložitý a častokrát zdĺhavý proces prerozdelenia spoločného majetku medzi manželov, ktorý musí zohl'adňovat' vel'ké množstvo faktorov súvisiacich $\mathrm{s}$ jeho nadobudnutím. V súčasnej dobe vzhl'adom aj na narastajúci trend rozvodovosti dochádza k nárastu počtu

14 Rozhodnutie Najvyššieho súdu Slovenskej republiky, sp. zn. 6 Cdo 128/2012: „Pod vyporiadaním treba rozumiet' nielen to, kto z bývalých spoluvlastnikov zostane vlastnikom tej ktorej veci a kto z nich vlastníctvo stráca, ale celkové komplexné riešenie majetkových vztahov medzi bývalými spoluvlastnikmi, vrátane pohl'adávok a dlhov, ktoré vznikli za trvania manželstva. Pri vyporiadani bezpodielového spoluvlastníctva manželov sa vychádza zo zásady rovnosti ich podielov, pričom platí, že v rovnakom pomere, v akom sa manželia podielajú na spoločnom majetku, sa podiel'ajú aj na spoločných dlhoch.“ 
zánikov BSM a ich následného vyporiadania, ktorý v značnej miere zvyšuje agendu už aj tak značne zat'ažených súdov. Aj z tohto dôvodu by bolo vhodné reflektovat' na spoločenský vývoj, ako aj potreby spoločnosti a určitým spôsobom umožnit' manželom širší legislatívny rozsah nakladania so spoločným majetkom (napr. prostredníctvom predmanželských zmlúv, alebo dohôd o zániku BSM počas manželstva).

\section{Literatúra:}

- BĚLOHLÁVEK, A. J. - ČERNÝ, F. - JUNGWIRTHOVÁ, M. - KLÍMA, P. PROFELDOVÁ. T. 2012. Nový Občanský zákonnik, Srovnání dosavadní a nové občanskoprávní úpravy včetne předpisů souvisejicich. Plzeň : Aleš Čeněk, 2012. 830 s. ISBN 978-80-7380-413-8.

- CIRÁK, J. - FICOVÁ, S. a kol. 2008. Občanské právo. Obecná část. Vydání první. Ostrava : KEY Publishing s.r.o., 2008. 359 s. ISBN 978-80-7418-002-6.

- ĎURANA, M. 2015. Nájom na neobvykle dlhú dobu alebo limity pre dojednania o dobe nájmu, In Štát a právo : vedecko-teoretický časopis pre otázky vedy o štáte a práve v Slovenskej republike. Roč. 2, č. 1, Bratislava : Občianske združenie Štát a právo, 2015. ISSN 1339-7753 s. 45-49.

- ĎURICA, M. 2019. Zákon o konkurze a reštrukturalizácii. Komentár. 3. vydanie. Praha : C. H. Beck, 2019, 1456 s. ISBN 978-80-7400-754-5.

- FEKETE, I. 2011. Občiansky zákonník 1. Vel'kýkomentár. Bratislava : Eurokódex, 2011. 1254 s. ISBN 978-80-89447-50-3.

- GANDŽALOVÁ, D. 2009. Bezpodielové spoluvlastníctvo manželov a podnikanie, In Pocta Sentě Radvanové: $k$ 80. narozeninám. Praha : ASPI - Wolters Kluwer, 2009. ISBN 978-80-7357-432-1 s. 173-187.

- PAVELKOVÁ, B. 2011. Zákon o rodine. Komentár. 1. vydanie. Praha : C,H.Beck, 2011, 655 s. ISBN 978-80-7400-359-2.

- PETRÍKOVÁ, L. 2017. Ochrana súkromia a rodiny vo svetle pracovného práva. In Notitiae Novae Facultatis Iuridicae Universitatis Matthiae Belii Neosolii. Roč. 21, Banská Bystrica : Belianum, 2017. ISBN 978-80-557-1232-1 s. 366-372.

- SAKTOROVÁ, L. 2019. Is there a private life free from forms of social control? In Hungarian journal of legal studies. Vol. 60, no. 1, Budapest' : Akadémiai Kiadó, 2019. ISSN 2498-5473, s. 86-94.

- SKALOŠ, M. 2020. Právny poriadok Československa v rokoch 1948-1989. 1. vyd. Banská Bystrica : Belianum, 2020, 368 s. ISBN 978-80-557-1679-4.

- SKALOŠ, M. 2016. Súkromné právo v historickom kontexte Slovenska, In Visegrad journal on human rights: vedecký časopis Fakulty práva Paneurópskej vysokej školy, Právnická fakulta, Užhorodská národná univerzita, Č. 4/2. Bratislava, Užhorod : Paneurópska vysoká škola, Užhorodská národná univerzita, 2016. ISSN 1339-7915, s. 28-39.

- ŠEVCOVÁ, K. 2016. Nová právna úprava cezhraničného dedenia v zmysle nariadenia EÚ č. 650/2012, In Notitiae Novae Facultatis Iuridicae Universitatis Matthiae Belii Neosolii. Roč. 20, 1. Banská Bystrica : Belianum, 2016. ISBN 97880-557-1100-3 s. 340-348. 
- ŠOŠKOVÁ, I. 2016. Manželstvo a manželsko-právne vzt’ahy vo svetle prvej kodifikácie československého rodinného práva 1949. Banská Bystrica : Belianum, 2016, 198 s. ISBN 978-80-557-1151-5.

- ŠTEVČEK, M. - DULAK, A. - BAJÁNKOVÁ, J. - FEČÍK, M. - SEDLAČKO, F. - TOMAŠOVIČ, M. a kol. 2019. Občiansky zákonník I. § 1-450. Komentár. 2. vydanie. Praha: C. H. Beck, 2019. 1754 s. ISBN 978-80-7400-770-5.

- ŠVESTKA, J. - SPÁČIL, J. - ŠKÁROVÁ M. - HULMÁK, M. a kol. 2009. Občanský zákoník I. §1 až 459. Komentář. 2. vydání. Praha: C.H. Beck, 2009. 1394 s. ISBN 978-80-7400-108-6.

\section{Summary: Current Issues of Settlement of Community Property of Spouses}

The article focuses on selected issues of settlement of community property of spouses. It points out the individual legal forms of settlement. It characterizes their significance and meaning, while also reflecting on the relevant case law. It points out selected specifics, that spouses may encounter when settling their community property. The article also consider possible future legislative progress in this area.

JUDr. Juraj Takáč, PhD. Univerzita Mateja Bela v Banskej Bystrici Právnická fakulta, Katedra občianskeho a pracovného práva Komenského 20, 97401 Banská Bystrica Slovenská republika e-mail: juraj.takac@umb.sk 